\title{
Stability and Efficacy of Anti-dermatophyte Creams From Extract of Kigelia africana Leaves
}

Fawehinmi $\mathrm{AB}^{1^{*}}$ and Oyedeji FO $^{2}$

${ }^{1}$ Nigeria Natural Medicine Development Agency Lagos, Nigeria

${ }^{2}$ Department of Chemistry, University of Ibadan, Nigeria

\begin{abstract}
Dermatophytosis are skin infections caused by dermatophytes which can be pathogenic for humans and animals by infecting the stratum corneum, nails, claws or hair and which now affect more than $20 \%-25 \%$ of the world populations especially in the developing countries. Drug resistance and toxicity associated with long-term treatment with existing antifungal drugs necessitate the search for new drugs to treat dermatophytosis. The juice of Kigelia africana leaves has been used by the natives to treat dermatophytosis. The leaves were extracted with water, ethanol and petroleum ether. Phytochemical analyses of the extracts were carried out. Agar disc discussion method was used to determine the antifungal activities against clinical isolates of Microsporum audouinii, Epidermophyton floccosum, Trichophyton mentagrophytes and Malassezia furfur. Herbal creams formulated with $0.5,1.0$ and $2.0 \mathrm{~g}$ $\mathrm{w} / \mathrm{w}$ of the extract were subjected to stability tests using standard methods. FTIR was used to determine if there were new functional groups formed during production of the herbal creams. Sensitivity and efficacy of the products were determined using animal model experiment.
\end{abstract}

The percentage yields of extracts are petroleum ether $6.3 \%$, aqueous $6.5 \%$, and ethanol $7.2 \%$. Percentage ethanol phytochemical composition indicated that for Alkaloid (4.67\%), saponins $(2.48 \%)$, flavonoids $(0.81 \%)$ and tannins $(1.05 \%)$. The emulsion produced was an oil-in-water emulsion and had a white colour with $\mathrm{pH}$ of 7.02 spread of emulsion, rubbing-in effect and stability to centrifugation was very high. The antifungal results showed that the petroleum ether and aqueous extracts had $10 \mathrm{~mm}$ zones of inhibition, while ethanol extract had $15 \mathrm{~mm}$ at $10,000 \mu \mathrm{g} / \mathrm{ml}$ against Trichophyton mentagrophytes. Against Microsporum audouinii, the results are petroleum ether and aqueous extracts $(10 \mathrm{~mm})$ and ethanol extract $(14 \mathrm{~mm})$. Against Epidermophyton floccosum, the results are petroleum ether and aqueous extracts $(10 \mathrm{~mm})$ while ethanol was $13 \mathrm{~mm}$. The zones of inhibition recorded by the extracts against Malassezia furfur are aqueous $4 \mathrm{~mm}$, petroleum ether $12 \mathrm{~mm}$ and ethanol $15 \mathrm{~mm}$ respectively. The results for FTIR showed a spectrum of C-N stretch which peaks at $1019.00 \mathrm{~cm}^{-1}$ for Ka cream. Also, an O-H stretch peak was observed at $3254.00 \mathrm{~cm}^{-1}$. Temperature stability tests carried out indicated increasing stability in the order Ka.water cream $<$ Ka.pet. Ether cream $<$ Ka.ethanol cream. Centrifuge testing indicated that there was no separation of the creams. Light testing indicated no change in the colour and odour of the products. There was no change observed in all the test samples during the freeze-thaw testing. Moisture loss on drying indicated Ka.W(6.37\%) $<\mathrm{Ka} . \mathrm{E}(6.79 \%)<\mathrm{Ka} . P e t(6.40 \%)$. Animal studies evaluation of the ethanolic formulations of the cream indicated that their efficacy against the dermatophytes is concentration dependent and the efficacy is in the order $E$. floccosum $(30.53 \mu \mathrm{m})<M$. audouinii $(31.37 \mu \mathrm{m})<M$. furfur $(36.22 \mu \mathrm{m})<$ T. mentagrophyte $(37.01 \mu \mathrm{m})$.

The results showed that Kigelia africana ethanol extract can be used in herbal cream formulations for the management of dermatophytosis.

Keywords: Dermatophytosis; Keratinization; Kigelia africana; Alkaloid; Malassezia furfur

\section{Introduction}

Dermatophytosis is a skin infection caused by dermatophytes and is treated through the use of synthetic chemical derivatives which have been reported to succumb to resistance by the dermatophytes with prolonged usage on the skin [1]. It is principally cosmetic in the initial stages. Some of these chemicals include derivate of azoles, naphthoquinones, aminosterol and morpholine. Moghimipour et al. [2] reported that non availability and high cost of new generation antibiotics and antifungals due to low purchasing power of developing countries contributes to resistance by the pathogens. He also reported toxicity associated with long-term treatment with antifungal drugs but natural products found in plants seem to avoid these side effects Babayi et al. [3] reported compatibility of medicinal plant metabolites with human systems. Scherrer et al. [4] said that the efficacy of synergistic effects of active medicinal plants metabolites in eradication of human pathogens cannot be over emphasized. Aghel et al. also reported the resistance of many pathogens to synthetic drug therapies.
Dermatophytes such as Trichopyhton mentagrophytes, Microsporium audouinii, Epidermophyton floccosum and Malassezia furfur are fungi that require keratin for growth. These fungi can cause superficial infections of the skin, hair, and nails. Dermatophytes are spread by direct contact from other people (anthropophilic organisms), animals (zoophilic organisms) and soil (geophilic organisms) [5]. Fungal infections of the skin and nail form the most numerous and widespread group of mycosis. The prevalence of superficial mycotic infections has risen to such a level in the last decade that skin mycosis now affect

*Corresponding author: AB Fawehinmi, Nigeria Natural Medicine Development Agency Lagos, Nigeria, Tel: 2348023225085; E-mail: akinnbank@yahoo.com Received December 05, 2018; Accepted December 11, 2018; Published December 17, 2018

Citation: Fawehinmi AB, Oyedeji FO (2018) Stability and Efficacy of Antidermatophyte Creams From Extract of Kigelia africana Leaves. Altern Integ Med 7: 274. doi: 10.4172/2327-5162.1000274

Copyright: (C) 2018 Fawehinmi AB, et al. This is an open-access article distributed under the terms of the Creative Commons Attribution License, which permits unrestricted use, distribution, and reproduction in any medium, provided the original author and source are credited. 
more than $20 \%-25 \%$ of the world's population [6]. Dermatophytes thrive at surface temperatures of $25^{\circ} \mathrm{C}-28^{\circ} \mathrm{C}$ and the skin infection are encouraged by warm and humid conditions. Therefore, superficial fungal infections are common in tropical countries and further exuberated by wearing thick clothing. Some other factors that encourage proliferation of dermatophytosis include crowded living conditions and very low socioeconomic status with skin to skin contact. Dermatophytosis can also increase due to the absence or poor medicare and a weakened immune system (e.g., those infected with HIV or taking immunosuppressive drugs).

The leaves of Kigelia africana called pandoro (West Nigeria) is used by the Yorubas for the treatment of skin diseases [7]. It belongs to the family Bignoniaceae, and is widely distributed in the south, central and West Africa [8]. Oyedeji and Bankole-Ojo [9] carried out Quantitative evaluation of the anti-psoriatic activity of sausage tree (Kigelia africana) using methanol and hexane extracts of the stem, bark, leaves and fruit of the plant. The results of their studies showed that the topical application of $K$. africana exhibited an important antipsoriatic activity with $K$. africana stem methanol extracts exhibiting the highest anti-psoriatic activity with little irritation potential. Agyare et al. investigated the antimicrobial and antioxidant properties of methanol leaf and stem bark extracts of Kigelia africana and methanol leaf and root extracts of Strophanthus hispidus and also determined the wound healing properties of the extracts. The antimicrobial activities of the methanol extracts were determined against two gram-positive and two gram-negative bacteria and a fungus using agar diffusion and micro-dilution methods. K. africana extracts $(7.5 \% \mathrm{w} / \mathrm{w})$ showed significant wound contraction at day 7 with $72 \%$ of wound closure whiles significant wound contractions were observed on day 11 for stem bark of K. africana, leaf and root extracts of S. hispidus. They also found out that wound tissues treated with the extracts showed improved collagenation, re-epitheliazition and rapid granulation formation compared with untreated wound tissues. The extracts were found to contain alkaloids, saponins, tannins, flavonoids, carbohydrates, and sapogenetic glycosides.

\section{Materials and Methods}

\section{Plant materials}

Leaves of $K$. africana were collected at the botanical gardens of the University of Ibadan. It was identified by the taxonomist and samples deposited at medicinal plants of Nigeria Herbarium of NNMDA. The plants were air dried in the shade and pulverized to fine-sized particles for solvent extraction processes.

\section{Preparation of plant extracts}

$200 \mathrm{~g}$ of the pulverized plant sample was extracted with ethanol and petroleum ether using soxhlet extraction method. Rotary evaporator was used to recover the solvent from the mixture at the boiling point of the solvents. Aqueous extract of the sample was obtained by placing 200 $\mathrm{g}$ of the pulverized sample in a blender and 1 litre of hot distilled water added to it. The mixture was then thoroughly blended for five minutes and then filtered using a Whatman filter paper grade 1. Excess water was removed using a rotary evaporator set at $100^{\circ} \mathrm{C}$.

\section{Determination of the phytochemical constituents}

The extract was evaluated for the presence of tannins, flavonoids, saponins and alkaloids using simple qualitative and quantitative methods of Trease and Evans (1989) and Sofowora (1993).
Micro-organisms: Clinical isolates of Microsporium aoudininn, Epidermophytonfloccosum, Trychophyton mentagrophyte and Malassezia furfur were obtained from Spectralab medical and diagnostic services, Sagamu, Ogun State.

Microbiological assay: Zones of inhibition was determined using the method as described by Irobi and Daramola (1994). $0.2 \mathrm{~g}$ of weighed extracts and $2.0 \mathrm{~mL}$ of mixture of DMSO and N-Hexane were used in preparing each stock of $10000 \mu \mathrm{g} / \mathrm{mL}$. The stocks were then serially diluted to obtain $1000 \mu \mathrm{g} / \mathrm{mL}, 100 \mu \mathrm{g} / \mathrm{mL}$ and $10 \mu \mathrm{g} / \mathrm{mL}$ respectively. The zone of inhibition were measured in $\mathrm{mm}$ and recorded. The zones of inhibition produced by the solvents alone were subtracted from those of the extracts and solvents in order to obtain the zones of inhibition due to the extracts alone.

Materials for emulsion formulation : Cosmetic grade stearic acid, cetyl alcohol, parafin oil and triethanolamine were all obtained from Akilapa market in Ibadan while de-ionize water was obtained from International Institute of Tropical Agriculture (IITA) Ibadan, Oyo State. All oil soluble substances were placed in a stainless steel container and heated to between $70^{\circ} \mathrm{C}-75^{\circ} \mathrm{C}$. All water-soluble substances were placed in another stainless steel container and heated to the same temperature. The oil phase was then added to the aqueous phase slowly with stirring. Heating was continued at the same temperature for about 10-15 minutes. The coarse emulsions formed were then cooled to about $35^{\circ} \mathrm{C}$ gradually. The emulsions were allowed to stay at room temperature for twelve hours and then homogenized with the aid of a mechanical stirrer. The samples were then poured into labeled containers. Four emulsions were formulated based on four different formularies and labeled A-D. Emulsions containing $0.5 \%, 1 \%$ and $2 \%$, of Kigelia africana ethanolic extracts were produced. The prepared herbal emulsions were then vigorously homogenized (Table 1).

Stability tests for the formulated emulsion: Stability tests were carried out on the emulsions following the methods as described by cannel whereby the temperature variation tests include storing the samples at $-10^{\circ} \mathrm{C}, 4^{\circ} \mathrm{C}, 30^{\circ} \mathrm{C}, 37^{\circ} \mathrm{C}$ and $45^{\circ} \mathrm{C}$ were carried out. All observations including $\mathrm{pH}$, colour and odour were noted and recorded (Table 2). The creams were made to pass through freeze thaw cycles testing which involves making the samples pass through three cycles of temperature testing by placing the samples at $-10^{\circ} \mathrm{C}$ for 24 hours and then at room temperature for 24 hours (Table 3 ). The creams were made to pass through centrifuge testing whereby the samples were heated to $50^{\circ} \mathrm{C}$ and they were then centrifuged for thirty minutes at 2000, 2500, 3000 and $4000 \mathrm{rpm}$ (Table 4). They were then inspected for signs to determine if the dispersed phase of the emulsion has separated and risen to the top. The creams were made to pass through light testing whereby they were placed in test tubes and also in the actual package. They were then put in the window where direct sun rays fell on them. This method is used to determine the sensitivity of the emulsions to the ultra violet radiation (Table 5). Moisture loss on drying/residue content of the creams were determined by weighing $2.0 \mathrm{~g}$ of the cosmetic emulsion into a dried petri dish and kept in the oven at $105^{\circ} \mathrm{C}$ for 2 hours after which they were taken out and cooled in a desiccator and weighed to a constant weight.

\section{In vivo anti-dermatophytic activity}

Ethical statement: The experimental procedures carried out in this study were in compliance with University of Ibadan ethics committee for the care and use of laboratory animals in line with approval number UI-ACUREC/App/12/2016/06. 
Citation: Fawehinmi AB, Oyedeji FO (2018) Stability and Efficacy of Anti-dermatophyte Creams From Extract of Kigelia africana Leaves. Altern Integ Med 7: 274. doi: 10.4172/2327-5162.1000274

Page 3 of 12

\begin{tabular}{|c|c|c|c|}
\hline Medicinal plants & Alkaloid (\%) & Saponin (\%) & Flavonoid (\%) \\
\hline K. africana & $4.67 \pm 0.11$ & $2.48 \pm 0.31$ & $0.81 \pm 0.62$ \\
\hline & Each value in the table is the average \pm standard deviation of triplicate experiments \\
\hline
\end{tabular}

Table 1: The percentage phytochemical composition of the ethanol extract.

\begin{tabular}{|c|c|c|c|}
\hline Concentration in $\mathbf{\mu g} / \mathbf{m L}$ & $\mathbf{1 0}$ & $\mathbf{1 0 0}$ & $\mathbf{1 0 0}$ \\
\hline T. mentagrophytes & 5 & $\mathbf{1 0 0 0 0}$ & 10 \\
\hline M. audouinii & - & 6 & 9 \\
\hline E. floccossum & 4 & 5 & 10 \\
\hline M. furfur & 4 & 5 & 8 \\
\hline
\end{tabular}

Table 2: Zones of Inhibition $(\mathrm{mm})$ of aqueous extract on microorganisms.

\begin{tabular}{|c|c|c|c|}
\hline Concentration in $\boldsymbol{\mu g} / \mathbf{m L}$ & $\mathbf{1 0}$ & $\mathbf{1 0 0}$ & $\mathbf{1 0 0 0}$ \\
\hline T. mentagrophytes & 9 & 10 & 14 \\
\hline M. audouinii & - & 10 & 12 \\
\hline E. floccossum & 8 & 10 & 14 \\
\hline M. furfur & 7 & 8 & 13 \\
\hline
\end{tabular}

Table 3: Zones of Inhibition $(\mathrm{mm})$ of ethanol extract on microorganisms.

\begin{tabular}{|c|c|c|c|c|}
\hline Concentration in $\mu \mathrm{g} / \mathrm{mL}$ & 10 & 100 & 1000 & 10000 \\
\hline T. mentagrophytes & 4 & 7 & 10 & 10 \\
\hline M. audouinii & - & 7 & 10 & 10 \\
\hline E. floccossum & 4 & 8 & 10 & 10 \\
\hline M. furfur & 3 & 5 & 11 & 12 \\
\hline
\end{tabular}

Table 4: Zones of Inhibition $(\mathrm{mm})$ of petroleum ether extract on microorganisms.

\begin{tabular}{|c|c|c|c|c|c|c|c|c|c|c|c|c|c|c|c|c|c|c|}
\hline Product & & Day 1 & & & 2 weeks & & & 4 week & & & 8 weeks & & & 12 week & & & 16 week & \\
\hline & $\mathrm{pH}$ & Colour & odour & $\mathrm{pH}$ & colour & odour & PH & colour & odour & $\mathrm{pH}$ & colour & odour & $\mathrm{pH}$ & colour & odour & $\mathrm{pH}$ & colour & odour \\
\hline Control & 7.02 & NCC & $\mathrm{NClO}$ & 7.02 & NCC & $\mathrm{NClO}$ & 7.02 & NCC & $\mathrm{NClO}$ & 7.02 & NCC & $\mathrm{NClO}$ & 7.02 & NCC & $\mathrm{NClO}$ & 7.02 & NCC & $\mathrm{NClO}$ \\
\hline Ka.W & 7.21 & NCC & $\mathrm{NClO}$ & 7.21 & NCC & $\mathrm{NClO}$ & 7.21 & NCC & $\mathrm{NClO}$ & 7.21 & NCC & $\mathrm{NClO}$ & 7.21 & NCC & $\mathrm{NClO}$ & 7.21 & NCC & $\mathrm{NClO}$ \\
\hline Ka.E & 7.25 & NCC & $\mathrm{NClO}$ & 7.25 & NCC & $\mathrm{NClO}$ & 7.25 & NCC & $\mathrm{NClO}$ & 7.25 & NCC & $\mathrm{NClO}$ & 7.25 & NCC & $\mathrm{NClO}$ & 7.25 & NCC & $\mathrm{NClO}$ \\
\hline Ka.Pet & 7.19 & NCC & $\mathrm{NClO}$ & 7.19 & NCC & $\mathrm{NClO}$ & 7.19 & NCC & $\mathrm{NClO}$ & 7.19 & NCC & $\mathrm{NClO}$ & 7.19 & NCC & $\mathrm{NClO}$ & 7.19 & NCC & $\mathrm{NClO}$ \\
\hline
\end{tabular}

Table 5: Effect of temperature $\left(-10^{\circ} \mathrm{C}\right)$ on cream samples after production.

Laboratory animals: Albino rats weighing between 150-200 $\mathrm{g}$ were obtained from the experimental animal unit of the faculty of Veterinary medicine of the University of Ibadan. They were kept in well ventilated rat cages with free access to water and feed and were left in this environment for two (2) weeks to acclimatize.

Selection and grouping of animals: The animals were randomly allocated to six (6) groups (5 rats/group) such that the difference in average weight did not exceed $5 \mathrm{~g}$. Each animal was used once in the experiment. The rats were then inoculated with the dermatophytes. One week after inoculation of the animals with the dermatophytes, the inoculated skin area of $2 \mathrm{~cm}^{2}$ were treated with the plants extracts and the formulated emulsions with plants extracts for seven days. At the end of seven days, the animals were euthanized by cervical dislocation.

Forty five (45) animals were required per batch and were grouped into 6 groups of 5 rats in a group.

- Group 1: Animals without any treatment-Negative control.

- Group 2: Animals treated with cream containing 1\% Clotrimazole (Standard drug)-Positive control.

- Group 3: Animals treated with placebo (Emulsion without any medicinal plants)-Positive control.

- Group 4a: Animals treated with $0.5 \%$ medicinal plant extract alone.
- Group 4b: Animals treated with emulsion containing 0.5\% medicinal plant extract.

- Group 5a: Animals treated with 1\% medicinal plant extract alone.

- Group 5b: Animals treated with emulsion containing $1 \%$ medicinal plant extract.

- Group 6a: Animals treated with 2\% medicinal plant extract alone.

- Group 6b: Animals treated with emulsion containing 2\% medicinal plant extract.

Histopathological studies: $2 \mathrm{~cm}^{2}$ skin areas were cut and put in $10 \%$ formalin for histo-pathological analysis. Skin biopsy samples were examined for presence of fungal hyphae, hair follicles, sebaceous gland, inflammation and tissue destruction using light microscope. (Culling CFA. Hand book of histo-pathological and histo-chemical techniques 1979; III edition).

Statistical analysis of data: Statistical analysis of data was carried out by one way ANOVA comparing all test groups $v s$ control followed by tukeys post hoc analysis. Data is reported as mean \pm SEM. $\mathrm{P} \leq 0.05$ was considered significant. Also epidermal thickness and keratin layer were obtained with the aid of calibrated Toupview software.

FTIR analysis: The oil sample and the products were qualitatively characterized by the FT-IR technique. These were obtained on a Perkin 
Elmer Fourier transform infrared spectrometer. The spectra were recorded between $4000-350 \mathrm{~cm}^{-1}$ using $\mathrm{KBr}$ discs.

\section{Results and Discussion}

The percentage yield of extracts by the solvents are in the order petroleum ether $(6.3 \%)<$ aqueous $(6.5 \%)<$ ethanol $(7.2 \%)$.

The percentage phytochemical composition of the ethanol extract is listed in Table 1.

\section{Antimicrobial Screening}

\section{Effect of aqueous extracts of $K$. africana against the microorganisms}

At $10000 \mu \mathrm{g} / \mathrm{mL}$, the activities of the extract were the same against three of the dermatophytes namely $T$. mentagrophytes, M. aoudinin and E. floccossum with zones of inhibition of $10 \mathrm{~mm}$ while it was $4 \mathrm{~mm}$ for $M$. furfur. At $1000 \mu \mathrm{g} / \mathrm{mL}$, the zones of inhibition were in the range 5-10 $\mathrm{mm}$ with effect on $M$. furfur $<E$. floccossum $<M$. audouinii $<T$. mentagrophytes. Activities were noticed for the extract against the dermatophytes at $100 \mu \mathrm{g} / \mathrm{mL}$ in the order E. floccossum < $M$. audouinii $<$ T. mentagrophytes $<M$. furfur. At $10 \mu \mathrm{g} / \mathrm{mL}$, there was no activity of the extract against $M$. audouinii, but the activity against the other microorganisms were in the order $M$. furfur=E. floccossum $<$ T. mentagrophytes (Table 2). The result shows that the extract was active against T. mentagrophytes, E. floccossum and M. furfur at all the concentrations though the activity is concentration dependent. The extract however has no activity against $M$. audouinii at $10 \mu \mathrm{g} / \mathrm{mL}$. Owolabi et al. [10] reported that the aqueous extract of Kigelia africana water extract exhibited no antibacterial or antifungal activity at low concentrations, but the low activity observed here could be attributed to the conclusion by Arti and Kanika who observed that phytochemicals in little quantities have definite physiological action on the human body to fight antimicrobials.

\section{Effect of ethanol extracts of $K$. africana against the microorganisms}

The activities of ethanol extract of the plant at $10000 \mu \mathrm{g} / \mathrm{mL}$ range from 13-15 $\mathrm{mm}$ (Table 3). The zones of inhibition against the dermatophytes are in the order E. floccossum $<M$. audouinii $<T$. mentagrophytes $=M$. furfur. There was noticeable reduction in activities of the extract as the concentration reduced to $1000 \mu \mathrm{g} / \mathrm{mL}$ with zones of inhibition in the range $11-14 \mathrm{~mm}$ with activity against the organisms in the order E. floccossum $<M$. audouinii $=M$. furfur $<$ T. mentagrophytes. At $100 \mu \mathrm{g} / \mathrm{mL}$, the activities were in the order $T$. mentagrophytes $=M$. audouinii $=E$. floccossum $<M$. furfur. However no activity of the extract was recorded against $M$. audouinii at $10 \mu \mathrm{g} / \mathrm{mL}$, but it was active against the other dermatophytes in the order M. furfur $<E$. floccossum $<T$. mentagrophytes. Previous study by Okafor et al. against the pathogens seems to agree with was observed in this study.

\section{Effect of petroleum ether extracts of $K$. africana against the}

\section{microorganisms}

The activities of petroleum ether extracts of $K$. africana against the dermatophytes at $10000 \mu \mathrm{g} / \mathrm{mL}$ range from $10-12 \mathrm{~mm}$ (Table 4) with effect on T. mentagrophytes $=M$. audouinii E. floccossum $<M$. furfur. At $1000 \mu \mathrm{g} / \mathrm{mL}$, there was no noticeable change in the activity compared to $10000 \mu \mathrm{g} / \mathrm{mL}$. However, the activity against the dermatophytes reduced at $100 \mu \mathrm{g} / \mathrm{mL}$ which ranges from 5-8 mm with effect on $M$. furfur $<T$. mentagrophytes $=M$. audouinii $<$ E. floccossum. It was observed that at $10 \mu \mathrm{g} / \mathrm{mL}$, the extract had no effect on $M$. audouinii while the zones of inhibition on T. mentagrophytes and E. floccossum were $4 \mathrm{~mm}$ and 3 $\mathrm{mm}$ on $M$. furfur. Though there has not been much work carried out on the petroleum ether extracts of the plant to enable us compare, but the results obtained are very close to what was obtained for the aqueous extract of the plant.

\section{Temperature stability testing}

The results of changes in colour, odour and $\mathrm{pH}$ from date of production through $2,4,8,12$ and $16^{\text {th }}$ week of production and stored at $-10^{\circ} \mathrm{C}$ and $4^{\circ} \mathrm{C}$ are presented in Tables 5 and 6 . At production through $4,8,12$ and $16^{\text {th }}$ week, the colour, odour and $\mathrm{pH}$ of the creams remain stable. This indicated that the temperature did not allow movement or dissociation of ions. At $30^{\circ} \mathrm{C}$, there was no change in colour and odour of all the samples throughout the weeks of test. However, the $\mathrm{pH}$ of control dropped from 7.02 to 7.00 after 2 weeks of production and remained stable till $4^{\text {th }}$ week. At $8^{\text {th }}$ week, the $\mathrm{pH}$ further dropped by 0.01 to 6.99 and remained stable till $16^{\text {th }}$ week. $\mathrm{pH}$ of 7.25 was measured for Ka.E sample on the day of production. However, after 2 weeks of production, the $\mathrm{pH}$ increased to 7.27 and remains stable till $16^{\text {th }}$ week of test (Table 7). pH of 7.19 was measured for Ka.Pet sample on the day of production. However, after 4 weeks of production, the $\mathrm{pH}$ inceased to 7.20 and remain stable till $16^{\text {th }}$ week of test. The same observation was made for $\mathrm{pH}$ of Ka.Pet sample which increased from 7.19 at production to 7.23 after 16 weeks of production. Same goes for Ka.W with increase in $\mathrm{pH}$ from 7.21 at the day of production to 7.26 at $16^{\text {th }}$ week of production. The results of changes in colour, odour and $\mathrm{pH}$ from date of production through $2,4,8,12$ and $16^{\text {th }}$ week of production and stored at $37^{\circ} \mathrm{C}$ is presented in Table 8 . No noticeable changes in colour and odour were observed for all the samples. The same observation was made for $\mathrm{pH}$ of Ka.E sample which increased from 7.25 at production to 7.30 after 16 weeks of production. The same observation was made for $\mathrm{pH}$ of Ka.Pet, sample which increased from 7.19 at production to 7.23 after 16 weeks of production.

The results of changes in colour, odour and $\mathrm{pH}$ from date of production through $2,4,8,12$ and $16^{\text {th }}$ week of production and stored at $45^{\circ} \mathrm{C}$ is presented in Table 9. No noticeable changes in colour and odour were observed for all the samples. The $\mathrm{pH}$ of Ka.W sample increased from 7.21 at production to 7.26 after 16 weeks of production. The same observation was made for $\mathrm{pH}$ of Ka.E sample which increased from 7.25 at production to 7.32 after 16 weeks of production and $\mathrm{pH}$ of Ka.Pet too increased from 7.19 to 7.25.

\begin{tabular}{|c|c|c|c|c|c|c|c|c|c|c|c|c|c|c|c|c|c|c|}
\hline \multirow[t]{2}{*}{ product } & \multicolumn{3}{|c|}{ Day 1} & \multicolumn{3}{|c|}{2 weeks } & \multicolumn{3}{|c|}{4 weeks } & \multicolumn{3}{|c|}{8 weeks } & \multicolumn{3}{|c|}{12 weeks } & \multicolumn{3}{|c|}{16 weeks } \\
\hline & $\mathrm{pH}$ & Colour & odour & pH & colour & odour & PH & colour & odour & $\mathrm{pH}$ & colour & odour & $\mathrm{pH}$ & colour & odour & pH & colour & odour \\
\hline Control & 7.02 & NCC & $\mathrm{NClO}$ & 7.02 & NCC & $\mathrm{NClO}$ & 7.02 & NCC & $\mathrm{NClO}$ & 7.02 & NCC & $\mathrm{NClO}$ & 7.02 & $\mathrm{NCC}$ & $\mathrm{NClO}$ & 7.02 & NCC & $\mathrm{NClO}$ \\
\hline Ka.W & 7.21 & NCC & $\mathrm{NClO}$ & 7.21 & NCC & $\mathrm{NClO}$ & 7.21 & $\mathrm{NCC}$ & $\mathrm{NClO}$ & 7.22 & NCC & $\mathrm{NClO}$ & 7.22 & NCC & $\mathrm{NClO}$ & 7.23 & NCC & $\mathrm{NClO}$ \\
\hline Ka.E & 7.25 & NCC & $\mathrm{NClO}$ & 7.25 & NCC & $\mathrm{NClO}$ & 7.25 & NCC & $\mathrm{NClO}$ & 7.25 & NCC & $\mathrm{NClO}$ & 7.25 & NCC & $\mathrm{NClO}$ & 7.25 & NCC & $\mathrm{NCIO}$ \\
\hline Ka.Pet & 7.19 & NCC & $\mathrm{NClO}$ & 7.19 & NCC & $\mathrm{NClO}$ & 7.19 & NCC & $\mathrm{NClO}$ & 7.19 & NCC & $\mathrm{NClO}$ & 7.19 & NCC & $\mathrm{NClO}$ & 7.19 & NCC & $\mathrm{NClO}$ \\
\hline
\end{tabular}


Citation: Fawehinmi AB, Oyedeji FO (2018) Stability and Efficacy of Anti-dermatophyte Creams From Extract of Kigelia africana Leaves. Altern Integ Med 7: 274. doi: 10.4172/2327-5162.1000274

Page 5 of 12

\begin{tabular}{|c|c|c|c|c|c|c|c|c|c|c|c|c|c|c|c|c|c|c|}
\hline \multirow[t]{2}{*}{ product } & \multicolumn{3}{|c|}{ Day 1} & \multicolumn{3}{|c|}{2 weeks } & \multicolumn{3}{|c|}{4 weeks } & \multicolumn{3}{|c|}{8 weeks } & \multicolumn{3}{|c|}{12 weeks } & \multicolumn{3}{|c|}{16 weeks } \\
\hline & pH & Colour & odour & $\mathrm{pH}$ & colour & odour & PH & colour & odour & $\mathrm{pH}$ & colour & odour & $\mathrm{pH}$ & colour & odour & $\mathrm{pH}$ & colour & odour \\
\hline Control & 7.02 & NCC & $\mathrm{NClO}$ & 7.00 & NCC & $\mathrm{NClO}$ & 6.99 & NCC & $\mathrm{NClO}$ & 6.98 & NCC & 1 & 6.98 & 1 & 1 & 6.98 & 1 & 1 \\
\hline Ka.W & 7.21 & NCC & $\mathrm{NClO}$ & 7.22 & NCC & $\mathrm{NClO}$ & 7.24 & NCC & $\mathrm{NClO}$ & 7.24 & 1 & 1 & 7.25 & 1 & 1 & 7.26 & 1 & 1 \\
\hline Ka.E & 7.25 & NCC & $\mathrm{NClO}$ & 7.25 & NCC & $\mathrm{NClO}$ & 7.27 & NCC & $\mathrm{NClO}$ & 7.27 & 1 & 1 & 7.27 & 1 & 1 & 7.27 & 1 & 1 \\
\hline Ka.Pet & 7.19 & NCC & $\mathrm{NClO}$ & 7.19 & NCC & $\mathrm{NClO}$ & 7.19 & NCC & $\mathrm{NClO}$ & 7.20 & 1 & 1 & 7.20 & 1 & 1 & 7.20 & 1 & 1 \\
\hline
\end{tabular}

Table 7: Effect of temperature $\left(30^{\circ} \mathrm{C}\right)$ on cream samples after production.

\begin{tabular}{|c|c|c|c|c|c|c|c|c|c|c|c|c|c|c|c|c|c|c|}
\hline \multirow[t]{2}{*}{ product } & \multicolumn{3}{|c|}{ Day 1} & \multicolumn{3}{|c|}{2 weeks } & \multicolumn{3}{|c|}{4 weeks } & \multicolumn{3}{|c|}{8 weeks } & \multicolumn{3}{|c|}{12 weeks } & \multicolumn{3}{|c|}{16 weeks } \\
\hline & $\mathrm{pH}$ & Colour & odour & $\mathrm{pH}$ & colour & odour & PH & colour & odour & $\mathrm{pH}$ & colour & odour & $\mathrm{pH}$ & colour & odour & $\mathrm{pH}$ & colour & odour \\
\hline Control & 7.02 & NCC & $\mathrm{NClO}$ & 7.02 & NCC & $\mathrm{NClO}$ & 7.02 & NCC & $\mathrm{NClO}$ & 7.02 & $\mathrm{NCC}$ & $\mathrm{NClO}$ & 7.02 & $\mathrm{NCC}$ & $\mathrm{NClO}$ & 7.02 & NCC & $\mathrm{NClO}$ \\
\hline Ka.W & 7.21 & NCC & $\mathrm{NClO}$ & 7.22 & NCC & $\mathrm{NClO}$ & 7.24 & $\mathrm{NClO}$ & $\mathrm{NClO}$ & 7.24 & $\mathrm{NClO}$ & $\mathrm{NClO}$ & 7.25 & NCC & $\mathrm{NClO}$ & 7.26 & NCC & $\mathrm{NClO}$ \\
\hline Ka.E & 7.25 & NCC & $\mathrm{NClO}$ & 7.27 & NCC & $\mathrm{NClO}$ & 7.27 & NCC & $\mathrm{NClO}$ & 7.27 & NCC & $\mathrm{NClO}$ & 7.30 & NCC & $\mathrm{NClO}$ & 7.30 & NCC & $\mathrm{NClO}$ \\
\hline Ka.Pet & 7.19 & NCC & $\mathrm{NClO}$ & 7.20 & NCC & $\mathrm{NClO}$ & 7.22 & NCC & $\mathrm{NClO}$ & 7.22 & NCC & $\mathrm{NClO}$ & 7.23 & NCC & $\mathrm{NClO}$ & 7.23 & NCC & $\mathrm{NClO}$ \\
\hline \multicolumn{19}{|c|}{$\mathrm{NCC}=$ No change in colour, $\mathrm{CC}=\mathrm{Change}$ in colour, $\mathrm{NCIO}=\mathrm{No}$ change in odour, $\mathrm{ClO}=$ Change in odour } \\
\hline \multicolumn{19}{|c|}{ Table 8: Effect of temperature $\left(37^{\circ} \mathrm{C}\right)$ on cream samples after production. } \\
\hline product & \multicolumn{3}{|c|}{ Day 1} & \multicolumn{3}{|c|}{2 weeks } & \multicolumn{3}{|c|}{4 weeks } & \multicolumn{3}{|c|}{8 weeks } & \multicolumn{3}{|c|}{12 weeks } & \multicolumn{3}{|c|}{16 weeks } \\
\hline & $\mathrm{pH}$ & Colour & odour & pH & colour & odour & PH & colour & odour & pH & colour & odour & $\mathrm{pH}$ & colour & odour & $\mathrm{pH}$ & colour & odour \\
\hline Control & 7.02 & NCC & $\mathrm{NClO}$ & 7.02 & $\mathrm{NCC}$ & $\mathrm{NClO}$ & 7.02 & NCC & $\mathrm{NClO}$ & 7.02 & NCC & $\mathrm{NClO}$ & 7.02 & NCC & $\mathrm{NClO}$ & 7.02 & NCC & $\mathrm{NClO}$ \\
\hline Ka.W & 7.21 & NCC & $\mathrm{NClO}$ & 7.23 & NCC & $\mathrm{NClO}$ & 7.23 & NCC & $\mathrm{NClO}$ & 7.25 & NCC & $\mathrm{NClO}$ & 7.25 & NCC & $\mathrm{NClO}$ & 7.26 & NCC & $\mathrm{NClO}$ \\
\hline Ka.E & 7.25 & NCC & $\mathrm{NClO}$ & 7.29 & NCC & $\mathrm{NClO}$ & 7.29 & NCC & $\mathrm{NClO}$ & 7.29 & NCC & $\mathrm{NClO}$ & 7.32 & NCC & $\mathrm{NClO}$ & 7.32 & NCC & $\mathrm{NClO}$ \\
\hline Ka.Pet & 7.19 & NCC & $\mathrm{NClO}$ & 7.21 & NCC & $\mathrm{NClO}$ & 7.21 & NCC & $\mathrm{NClO}$ & 7.24 & NCC & $\mathrm{NClO}$ & 7.24 & NCC & $\mathrm{NClO}$ & 7.25 & NCC & $\mathrm{NClO}$ \\
\hline
\end{tabular}

Table 9: Effect of temperature $\left(45^{\circ} \mathrm{C}\right)$ on cream samples after production.

\section{Centrifuge testing}

No phase separation was detected in all the test samples at 2000 , 2500, 3000 and 4,000 rpm as indicated in Table 10. This shows that the disperse phase is well particulated in the continuous phase thereby stable to centrifugation.

\section{Light testing}

As shown in Table 11, no changes were noticed for all the samples which indicated that they were not sensitive to ultra violet light.

\section{Freeze-thaw testing}

There was no change observed in all the test samples during the cycle testing (Table 12).

Table 13 shows the results for moisture loss on drying/residue content which suggest that the formulations may be stable to microbial attack because of the moisture content which falls within the acceptable limits.

\section{Fourier transform infra-red spectrocopy analysis}

Results of FTIR spectroscopic studies revealed the presence of various functional groups in the cream and the test sample (Figures 1 and 2). The spectrum of the placebo (cream alone) shows strong $\mathrm{O}-\mathrm{H}$ stretch at $3373.00 \mathrm{~cm}^{-1}$ of amines. $\mathrm{N}=\mathrm{H}$ bending at $1640.00 \mathrm{~cm}^{-1}$ indicated that the placebo contains an unsaturated amide group. $\mathrm{O}-\mathrm{H}$ bending of phenyl group at $1409.00 \mathrm{~cm}^{-1}$ indicated the presence of carboxylic acid group in the sample, $\mathrm{S}=\mathrm{O}$ stretch at $1040.00 \mathrm{~cm}^{-1}$ indicated presence of sulphoxide. There is a spectrum of C-N stretch which peaks at $1019.00 \mathrm{~cm}^{-1}$ for Ka cream, this peak serves as good evidence for the homo-polymerization reaction. Also, an $\mathrm{O}-\mathrm{H}$ stretch peak was observed at $3254.00 \mathrm{~cm}^{-1}$. Some of these functional groups found in the herbal cream formulations which are not in the cream base maybe responsible for the plants effectiveness in the management of dermatophytosis.

\begin{tabular}{|c|c|c|c|c|}
\hline Sample & $\mathbf{2 0 0 0} \mathbf{~ r p m}$ & $\mathbf{2 5 0 0} \mathbf{~ r p m}$ & $\mathbf{3 0 0 0} \mathbf{~ r p m}$ & $\mathbf{4 0 0 0} \mathbf{~ r p m}$ \\
\hline control & NPS & NPS & NPS & NPS \\
\hline Ka.W & NPS & NPS & NPS & NPS \\
\hline Ka.E & NPS & NPS & NPS & NPS \\
\hline Ka.Pet & NPS & NPS & NPS & NPS \\
\hline \multicolumn{4}{|c}{ NPS $=$ No phase separation, PS=phase separation } \\
\end{tabular}

Table 10: Centrifuge testing for the samples.

\begin{tabular}{|c|c|}
\hline Control & NNC \\
\hline Ka.w & NCC \\
\hline Ka.E & NCC \\
\hline Ka.et & NCC \\
\hline NCC=No colour change, CC=colour change \\
\hline
\end{tabular}

Table 11: Light testing.

\begin{tabular}{|c|c|}
\hline Control & NPS \\
\hline Ka.w & NPS \\
\hline Ka.E & NPS \\
\hline Ka.et & NPS \\
\hline NPS=No Phase separation, PS=Phase separation \\
\hline
\end{tabular}

Table 12: Freeze thaw testing.

\begin{tabular}{|c|c|c|}
\hline Cream & $\begin{array}{c}\text { Moisture loss on drying } \\
\text { (\%) }\end{array}$ & Residue content (\%) \\
\hline Kigelia africana aqueous & 6.37 & 93.63 \\
\hline Kigelia africana ethanol & 6.39 & 93.61 \\
\hline Kigelia africana pet.ether & 6.40 & 93.60 \\
\hline
\end{tabular}

Table 13: Determination of moisture loss on drying/residue content of medicinal plants extracts emulsions.

\section{In vivo Anti-dermatophytic Activity}

Efficacy of Kigelia africana ethanol cream formulations against Microsporum audouinii

Marked inflammation of the skin and foci of discontinuity of the 


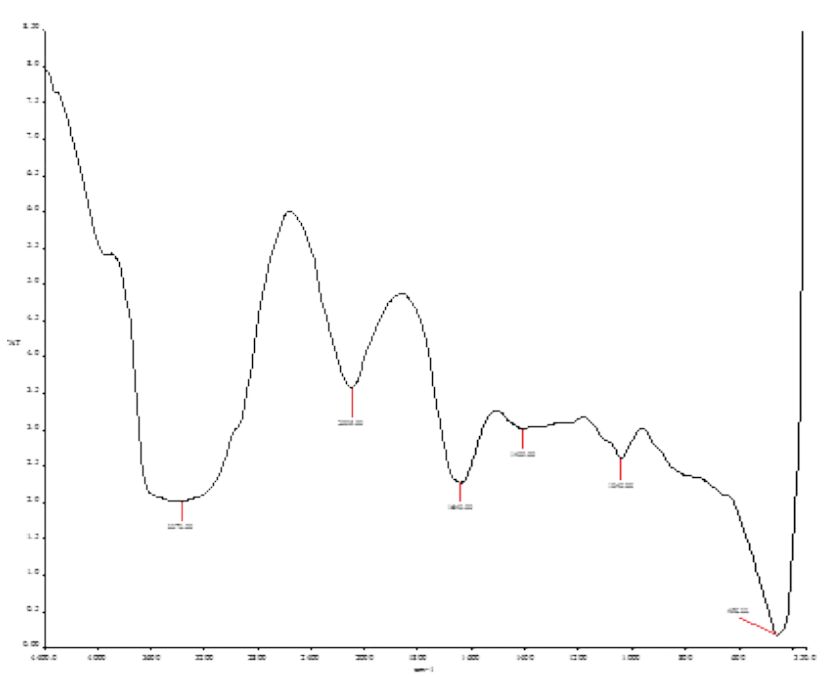

Figure 1: FTIR spectrum of emulsion alone (placebo)

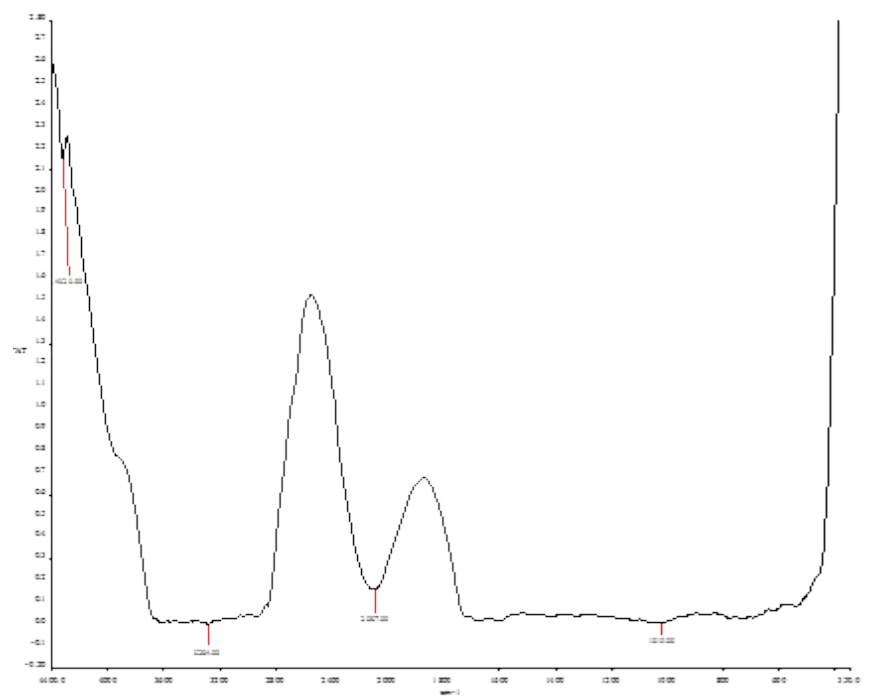

Figure 2: FTIR spectrum of Kigelia africana cosmeutical.

epidermis were observed in the untreated group (group 1) which confirms successful infection (Table 14). There was marked presence of fungal hyphae as shown in Figure 3. There were few hair follicles enmeshed within the sparse connective tissue in the dermis which indicated that the dermatophyte is feeding on the follicles (Figure 3 ). Very few sebaceous glands were seen showing that the oil in the sebaceous gland have been used up by the dermatophytes. Marked tissue destruction was observed. In the group treated with emulsion alone (group 3), Inflammation and tissue destruction of the skin were moderate in the group. There was marked presence of fungal hyphae which indicated that the cream alone has no medicinal effect on the dermatophyte infection and reduction of numbers of hair follicles also occurred as the dermatophye was able to attack unhindered. However the group has moderate number of sebaceous glands in the dermis showing the content of the emulsion provided alternative source for the dermatophyte thus reducing the effect on the glands.

In group $4 \mathrm{a}(0.5 \%$ plant extract alone), Inflammation and tissue destruction of the skin were moderate in the group (Table 14). Presence

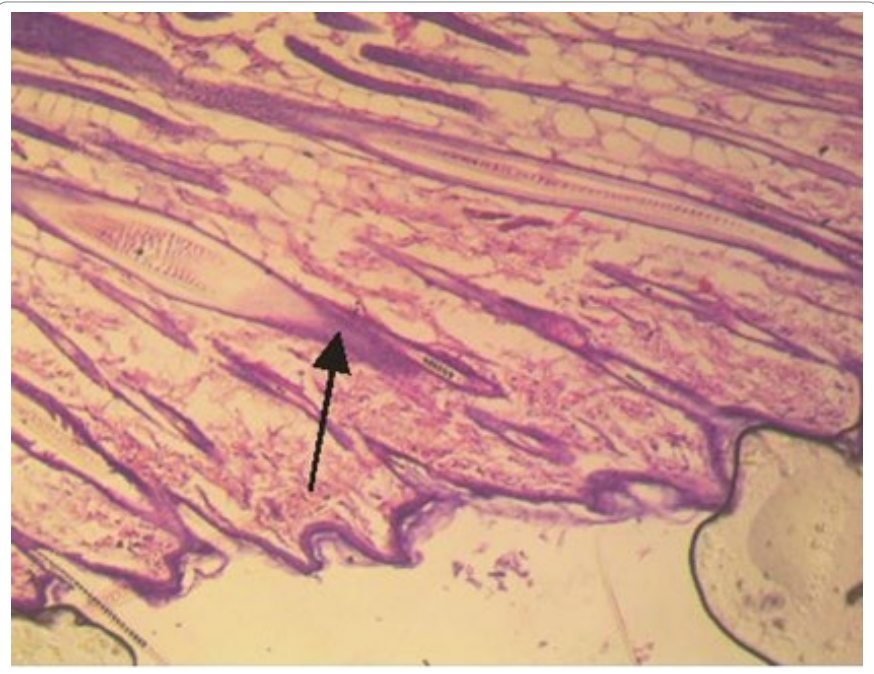

Figure 3: Fungal hyphae in the untreated control H\&E stain, 100X.

\begin{tabular}{|r|c|c|c|c|c|}
\hline Group & $\begin{array}{c}\text { Fungal } \\
\text { hyphae }\end{array}$ & $\begin{array}{c}\text { Hair } \\
\text { follicles }\end{array}$ & $\begin{array}{c}\text { Sebaceous } \\
\text { gland }\end{array}$ & Inflammation & $\begin{array}{c}\text { Continuity/Tissue } \\
\text { destruction }\end{array}$ \\
\hline 1 & +++ & + & + & +++ & +++ \\
\hline 2 & - & +++ & +++ & - & - \\
\hline 3 & +++ & + & ++ & ++ & ++ \\
\hline $4 a$ & ++ & + & ++ & ++ & ++ \\
\hline $4 b$ & ++ & + & ++ & ++ & ++ \\
\hline $5 a$ & + & ++ & ++ & + & + \\
\hline $5 b$ & + & ++ & ++ & + & + \\
\hline $6 a$ & - & ++ & ++ & - & + \\
\hline $6 b$ & - & ++ & +++ & - & + \\
\hline & \multicolumn{7}{c}{ Absent =-, Mild=+, Moderate=++, Marked=+++ } \\
\hline
\end{tabular}

Table 14: Mycological efficacy of Kigelia africana formulations on Microsporum audouinii.

of fungal hyphae was also moderate while there was moderate number of hair follicles enmeshed within the sparse connective tissue in the dermis. There are moderate numbers of sebaceous glands in the dermis. Presence of fungal hyphae was moderate in group $4 \mathrm{~b}(0.5 \%$ plant extract in emulsion). There are moderate hair follicles enmeshed within the sparse connective tissue in the dermis. There were also moderate numbers of sebaceous glands in the dermis. Inflammation and tissue destruction of the skin were also moderate in the group (Table 14). In groups $5 \mathrm{a}$ ( $1 \%$ plant extract alone), the inflammation and tissue destruction of the skin were moderate and same observation were recorded for $5 \mathrm{~b}$ ( $1 \%$ plant extract in emulsion). Few numbers of fungal hyphae were seen with moderate amount of hair follicle and sebaceous gland. In group $6 \mathrm{a}$ ( $2 \%$ plant extract alone), no inflammation of the skin was seen but mild tissue destruction was however observed in the group. No fungal hyphae were seen which indicated that the extract was able to prevent the growth of the hyphae by the dermatophyte (Figure 4). There were moderate hair follicles in the dermis and also moderate amount of sebaceous glands. This may be as a result of the bio-actives in the extracts not been able to stop the growth of the fungal hyphae until after several applications. Same observation was made for group $6 \mathrm{~b}(2 \%$ plant extract in emulsion) except for the abundance of sebaceous glands in the dermis which may have been on account of the fat in the emulsion been available as alternative to the oil in the sebaceous glands. This shows that $2 \%$ plant extract alone and $2 \%$ plant extract in emulsion are significantly effective as the standard drug in preventing the secretion 


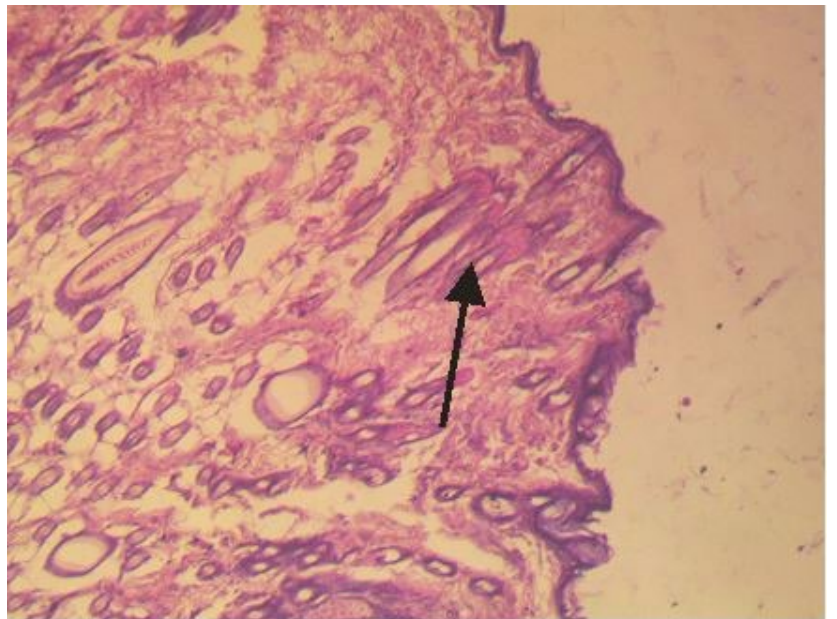

Figure 4: Shows the structure of intact skin from treated control with $1 \%$ clotrimazole H\&E stain, $100 X$

of keratinase which plays a vital role in the process of infection by Microsporum audouinii. From the results above, there is clear indication that efficacy of the formulations is concentration dependent.

Figure 5 shows the effect of the formulations on de-keratinization. Higher scores indicated improved efficacy. The untreated group 1 with the value $16.20 \pm 0.76 \mu \mathrm{m}$ indicated significant de-keratinization. Group 2 which is the standard drug ( $1 \%$ clotrimazole cream) showed high efficacy $(39.45 \pm 0.82 \mu \mathrm{m})$ indicating that it was able to reduce de-keratinization significantly by the dermatophyte. Emulsion alone (placebo), $0.5 \%$ Kigelia africana extract and $0.5 \%$ Kigelia africana extract emulsion cannot be said to be mycologically effective compared to the values obtained for the other formulations. However, $1 \%$ Kigelia africana extract alone and $1 \%$ Kigelia africana extract emulsion showed slight efficacy, but not as effective as the $2 \%$ Kigelia africana extract alone and $2 \%$ Kigelia africana extract emulsions which showed comparative efficacy with the standard drug.

Epidermal thickness of the skin biopsies ranged from $41.62 \pm$ 0.58-92.37 $\pm 1.76 \mu \mathrm{m}$ (Figure 6). Higher value indicates significant infection of the dermis with attendance inflammation of the skin and tissue destruction. The untreated group 1 with the value of $92.37 \pm$ $1.76 \mu \mathrm{m}$ indicated significant infection. Group 2 which is the standard drug ( $1 \%$ clotrimazole cream) showed that the drug was able to reduce the epidermal thickness significantly $(36.52 \pm 0.54 \mu \mathrm{m})$. The values obtained for emulsion alone $(89.38 \pm 0.56 \mu \mathrm{m})$ was not different from the untreated group. However, the efficacy of $0.5 \%$ Kigelia africana extract, $0.5 \%$ Kigelia africana extract emulsion, $1 \%$ Kigelia africana extract and $1 \%$ Kigelia africana emulsion in reducing the epidermal thickness is not significant compared with the untreated control. In contrast, there was significant efficacy of $2 \%$ Kigelia africana extract and $2 \%$ Kigelia africana emulsion compared with the values obtained for the standard drug.

\section{Efficacy of Kigelia africana ethanol cream formulations against Epidermophyton floccosum}

Group 1 animals which are the untreated infected group showed marked inflammation of the skin and foci of discontinuity of the epidermis (Figure 7). Marked tissue destruction was also observed in the group compared to the other groups which were treated with various formulations. There was marked presence of fungal hyphae which

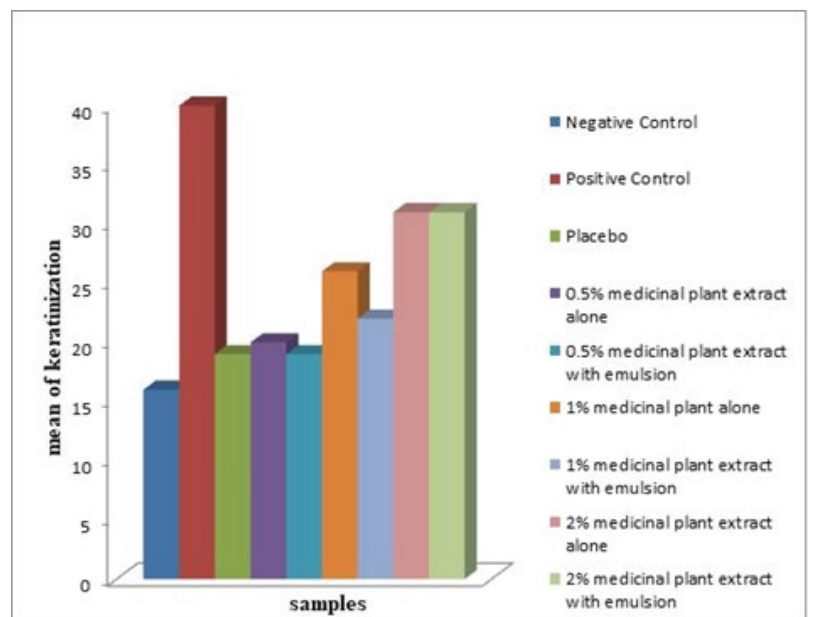

Figure 5: Effect of Kigelia africana extracts on keratinization in Microsporium aoudinin infected skin.

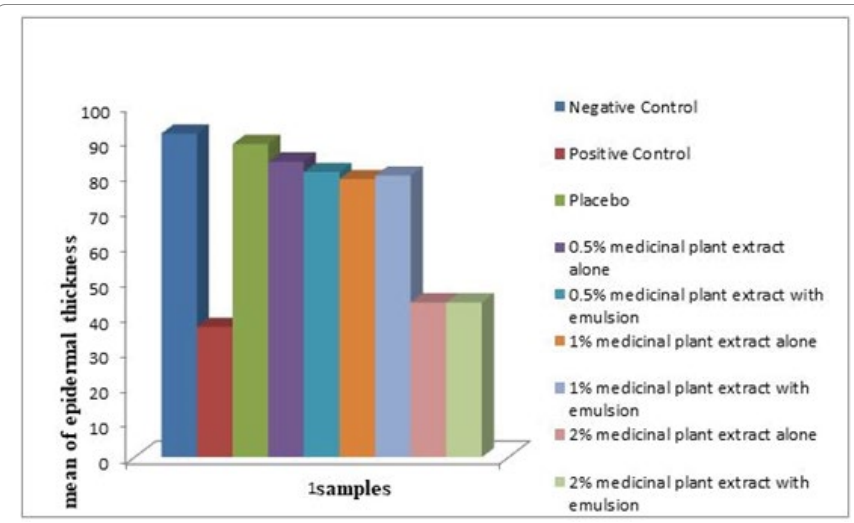

Figure 6: Effect of Kigelia africana extracts on epidermal thickness in Microsporium aoudinin infected skin.

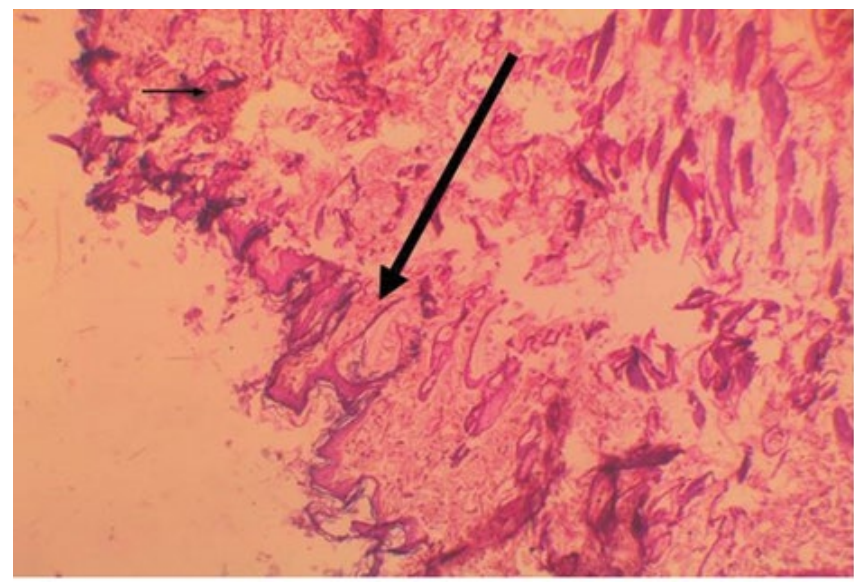

Figure 7: Inflammation of the skin tissue, H\&E stain, 100X.

implies successful infection by the dermatophyte. No hair follicles were seen this implies that the dermatophyte fed on the follicles. There were very few sebaceous glands. No inflammation and tissue destruction was observed in the group treated with $1 \%$ clotrimazole (group 2) showing that the drug was able to prevent the growth of the hyphae by the dermatophyte. No fungal hyphae were seen in the group. There 
were numerous hair follicles in the dermis and also moderate amount of sebaceous glands. Group 3 animals were treated with emulsion alone. Skin inflammation was marked while tissue destruction of the skin was moderate (Table 15). There was marked presence of fungal hyphae which indicated that the cream alone has no medicinal effect on the dermatophyte infection which a reduction of numbers in hair follicles. However there are few sebaceous glands in the dermis (Figure 8).

In group $4 \mathrm{a}$, the animals were treated with $0.5 \%$ plant extract alone. Inflammation and tissue destruction of the skin were moderate in the group (Table 15). Presence of fungal hyphae was moderate while there were few hair follicles enmeshed within the sparse connective tissue in the dermis. There were few sebaceous glands in the dermis. Skin inflammation was moderate and tissue destruction of the skin were also mild (Table 15$)$ in group $4 \mathrm{~b}$ (0.5\% plant extract in emulsion). Presence of fungal hyphae was few. There were few hair follicles enmeshed within the sparse connective tissue in the dermis. There are also few sebaceous glands in the dermis. In group $5 \mathrm{a}$ ( $1 \%$ plant extract alone), the inflammation and tissue destruction of the skin were mild. Few amounts of fungal hyphae were seen with few amounts of hair follicle and sebaceous gland. Same observation were recorded for group $5 b(1 \%$ plant extract in emulsion).

No inflammation of the skin and tissue destruction was seen in group 6 a (2\% plant extract alone) which indicated that the extract was able to prevent the growth of the dermatophyte hyphae. No fungal hyphae were seen. There were moderate hair follicles in the dermis

\begin{tabular}{|r|c|c|c|c|c|}
\hline Group & $\begin{array}{c}\text { Fungal } \\
\text { hyphae }\end{array}$ & $\begin{array}{c}\text { Hair } \\
\text { follicles }\end{array}$ & $\begin{array}{c}\text { Sebaceous } \\
\text { gland }\end{array}$ & Inflammation & $\begin{array}{c}\text { Continuity/Tissue } \\
\text { destruction }\end{array}$ \\
\hline 1 & +++ & - & + & +++ & +++ \\
\hline 2 & - & +++ & ++ & - & - \\
\hline 3 & +++ & + & + & +++ & ++ \\
\hline $4 a$ & ++ & + & + & ++ & ++ \\
\hline $4 b$ & + & + & + & ++ & + \\
\hline $5 a$ & + & + & + & + & + \\
\hline $5 b$ & + & + & + & + & + \\
\hline $6 a$ & - & ++ & ++ & - & - \\
\hline $6 b$ & - & ++ & ++ & - & - \\
\hline \multicolumn{7}{|c|}{ Absent =-, Mild=+, Moderate=++, Marked=+++ } \\
\hline
\end{tabular}

Table 15: Mycological efficacy of Kigelia africana formulations on Epidermophyton floccosum infected skin.

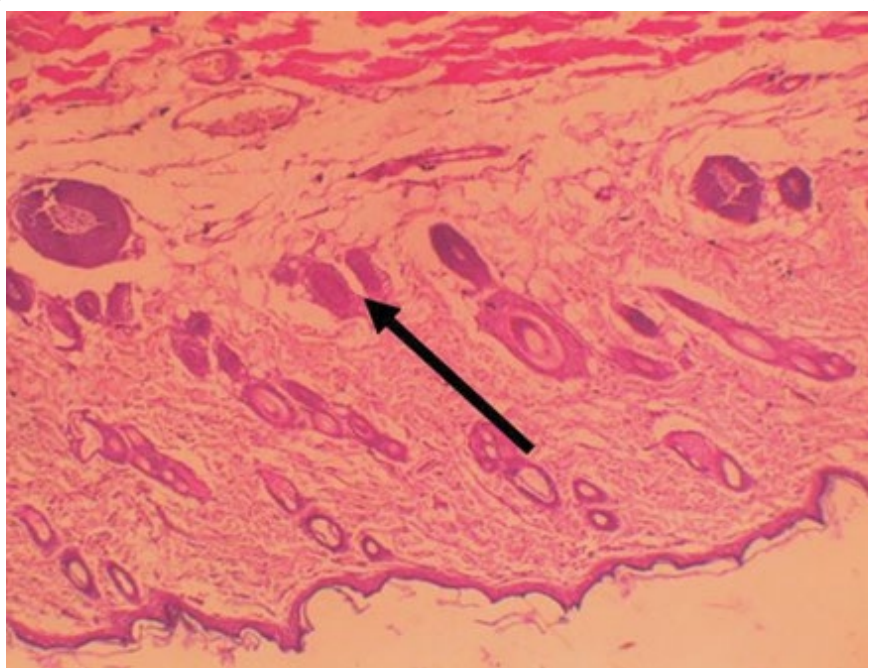

Figure 8: The inoculums of microconidia in follicular openings H\&E stain 100X. and also moderate amount of sebaceous glands. Same observation was made for group $6 \mathrm{~b}$ ( $2 \%$ plant extract in emulsion). This indicated that $2 \%$ plant extract alone and $2 \%$ plant extract in emulsion are significantly effective as the standard drug.

Figure 9 shows the effect of the formulations on the keratin layer of the hair. The untreated control with the value $13.37 \pm 0.39$ indicated that the hairs were heavily infected with the dermatophyte. The effectiveness of $1 \%$ clotrimazole cream $(39.86 \pm 0.21 \mu \mathrm{m})$ in preventing attack by the dermatophyte on the keratin layer of the hair is demonstrated by the high value recorded. However, the group treated with the emulsion alone $(15.30 \pm 0.22 \mu \mathrm{m})$ and the group treated with $0.5 \%$ Kigelia africana extract emulsion $(15.25 \pm 0.28 \mu \mathrm{m})$ was not too different from the untreated group. $0.5 \%$ Kigelia africana extract, $1 \%$ Kigelia africana extract alone and 1\% Kigelia africana emulsion showed slight efficacy compared to the untreated control. Comparatively, $2 \%$ Kigelia africana extract alone $(30.94 \pm 0.38 \mu \mathrm{m})$ and $2 \%$ Kigelia africana extract emulsion $(30.53 \pm 0.25 \mu \mathrm{m})$ showed mycological efficacy to other formulations.

Figure 10 showed the untreated group 1 with the value of $92.37 \pm$ $1.76 \mu \mathrm{m}$ which indicated significant infection. Group 2 which is the standard drug ( $1 \%$ clotrimazole cream) showed that the drug was able to reduce the epidermal thickness significantly $(36.52 \pm 0.54 \mu \mathrm{m})$. The values obtained for emulsion alone $(89.38 \pm 0.56 \mu \mathrm{m})$ was not statistically different from the untreated group. However, the efficacy of $0.5 \%$ Kigelia a fricana extract, $0.5 \%$ Kigelia africana extract emulsion, $1 \%$ Kigelia africana extract and $1 \%$ Kigelia africana emulsion in reducing the epidermal thickness is not significant compared with the untreated control. In contrast, there was significant efficacy of $2 \%$ Kigelia africana extract and $2 \%$ Kigelia africana emulsion compared with the values obtained for the standard drug.

\section{Efficacy of Kigelia africana ethanol cream formulations against Trichophyton mentagrophytes}

There was marked inflammation of the skin and foci of discontinuity of the epidermis in group 1 (Table 16). Marked presence of fungal hyphae shows successful infection. There were no hair follicles seen and few sebaceous glands were found. Marked tissue destruction was also

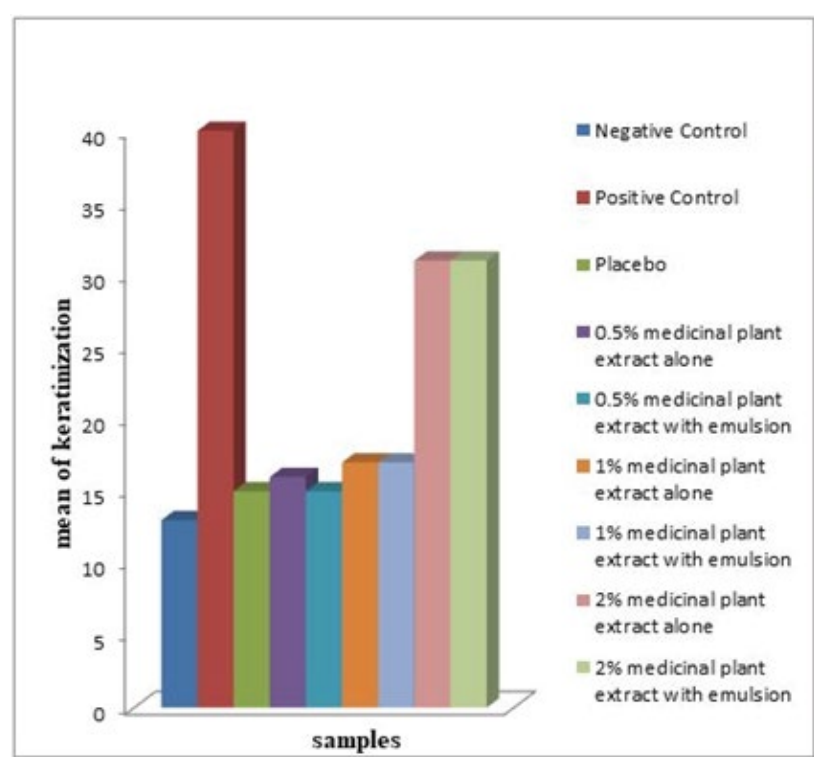

Figure 9: Effect of Kigelia africana extracts on keratinization levels in Epidermophyton floccosum infected skin. 


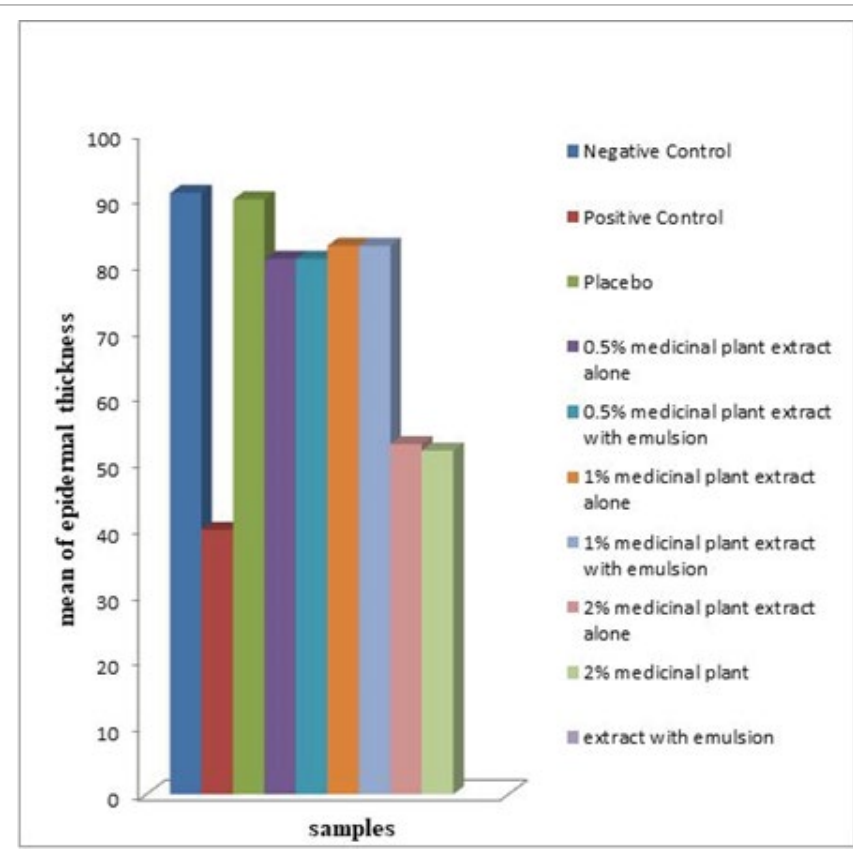

Figure 10: Effect of Kigelia africana extracts on epidermal thickess in Epidermophyton floccosum infected skin.

\begin{tabular}{|c|c|c|c|c|c|}
\hline Group & $\begin{array}{c}\text { Fungal } \\
\text { hyphae }\end{array}$ & $\begin{array}{c}\text { Hair } \\
\text { follicles }\end{array}$ & $\begin{array}{c}\text { Sebaceous } \\
\text { gland }\end{array}$ & Inflammation & $\begin{array}{c}\text { Continuityl } \\
\text { Tissue } \\
\text { destruction }\end{array}$ \\
\hline 1 & +++ & - & + & +++ & ++ \\
\hline 2 & - & +++ & +++ & - & - \\
\hline 3 & ++ & + & + & ++ & ++ \\
\hline $4 a$ & + & ++ & + & ++ & ++ \\
\hline $4 b$ & + & ++ & + & ++ & ++ \\
\hline $5 a$ & + & ++ & ++ & + & + \\
\hline $5 b$ & + & ++ & ++ & + & + \\
\hline $6 a$ & - & +++ & ++ & + & + \\
\hline $6 b$ & - & ++ & ++ & + & + \\
\hline
\end{tabular}

Table 16: Mycological efficacy of Kigelia africana ethanol formulations against Trichophyton mentagrophytes.

observed in the group compared to the other groups which were treated with various formulations (Figure 11). No inflammation and tissue destruction was observed in group 2 (Table 16). There was absence of fungal hyphae indicating that the drug was able to prevent the infection by the dermatophyte. Numerous hair follicles and sebaceous glands were seen in the dermis. Group 3 animals treated with emulsion alone had moderate Inflammation and tissue destruction of the skin. There were few presences of fungal hyphae and also few hair follicles. Few sebaceous glands were also seen in the dermis (Figure 12). There was little presence of fungal hyphae in group 4a. Moderate amount of hair follicles enmeshed within the sparse connective tissue in the dermis were seen. There are few sebaceous glands in the dermis. Same observations made for group $4 \mathrm{a}$ were also seen in group $4 \mathrm{~b}$.

The inflammation and tissue destruction of the skin were also mild in group $5 \mathrm{a}$ ( $1 \%$ plant extract alone) (Table 16). Few amounts of fungal hyphae were seen with moderate amount of hair follicle and sebaceous gland. Same observation were recorded for $5 b$ ( $1 \%$ plant extract in emulsion). In group $6 \mathrm{a}$ ( $2 \%$ plant extract alone), mild inflammation of

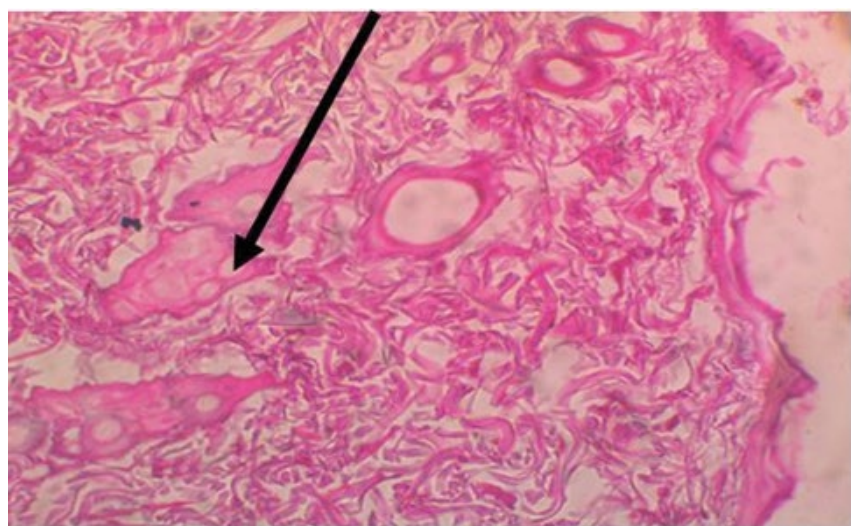

Figure 11: Hyperkeratosis, telogen follicles and absence of sebaceous gland, H\&E stain, $100 X$

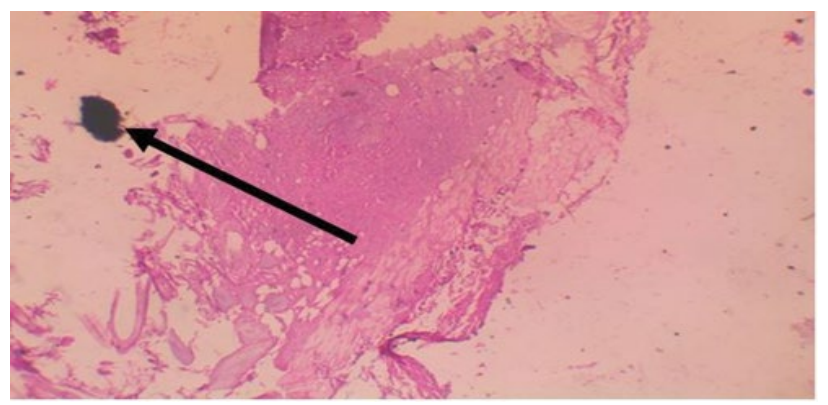

Figure 12: Tissue destruction of the skin tissues, H\&E stain, 100X.

the skin and tissue destruction was seen. No fungal hyphae were seen which indicated that the extract was able to prevent the growth of the dermatophyte hyphae. There were numerous hair follicles in the dermis and also moderate amount of sebaceous glands. Same observation was made for group $6 \mathrm{~b}$ ( $2 \%$ plant extract in emulsion). This shows that $2 \%$ plant extract alone and $2 \%$ plant extract in emulsion are closely effective as the standard drug.

The efficacy of the formulations on the keratin layer of the hair compared with the infected untreated control is shown in Figure 13. The untreated control group 1 , with the value $11.37 \pm 0.18 \mu \mathrm{m}$ indicated that the hairs were heavily infected with the dermatophyte. The standard drug ( $1 \%$ clotrimazole cream) with the value $42.83 \pm 0.33 \mu \mathrm{m}$ showed mycological efficacy in preventing attack by the dermatophyte on the keratin layer of the hair. However, the values obtained for group 3 (18.82 $\pm 0.22 \mu \mathrm{m})$, group $4 \mathrm{a}(21.50 \pm 0.44 \mu \mathrm{m})$ and group $4 \mathrm{~b}(20.87 \pm 0.60 \mu \mathrm{m})$ indicated that their efficacies were not different from one another. This implies that though infected by the dematophytes but not as heavily infected as the untreated control. The values obtained for groups $5 \mathrm{a}$ and $5 \mathrm{~b}$ indicated slight efficacy by the formulations. Comparatively, group $6 \mathrm{a}(38.84 \pm 0.52 \mu \mathrm{m})$ and group $6 \mathrm{~b}(37.01 \pm 0.39 \mu \mathrm{m})$ had close efficacy with the standard drug.

There was significant infection $(74.01 \pm 0.68 \mu \mathrm{m})$ as indicated by the result obtained for the epidermal thickness of untreated group (Figure 14). The values obtained for group $2(40.41 \pm 0.42 \mu \mathrm{m})$ indicated high efficacy by reducing the epidermal thickness. However, the values obtained for group $3(61.81 \pm 0.77 \mu \mathrm{m})$, group $4 \mathrm{a}(62.45 \pm 0.86 \mu \mathrm{m})$, group $4 \mathrm{~b}(62.45 \pm 0.60 \mu \mathrm{m})$, group $5 \mathrm{a}(60.72 \pm 0.58 \mu \mathrm{m})$ and group $5 \mathrm{~b}(60.01 \pm 0.42 \mu \mathrm{m})$ in reducing the epidermal thickness cannot be said to be significant compared with the untreated control. The values 
Citation: Fawehinmi AB, Oyedeji FO (2018) Stability and Efficacy of Anti-dermatophyte Creams From Extract of Kigelia africana Leaves. Altern Integ Med 7: 274. doi: 10.4172/2327-5162.1000274

Page 10 of 12

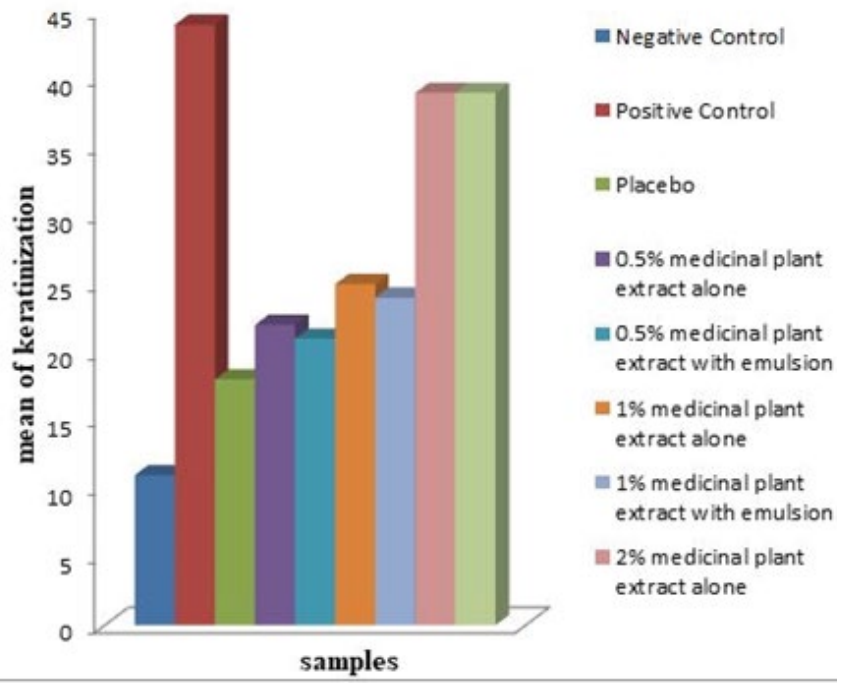

Figure 13: Effect of Kigelia africana extracts on keratinization in Trichophyton mentagrophyte infected skin.

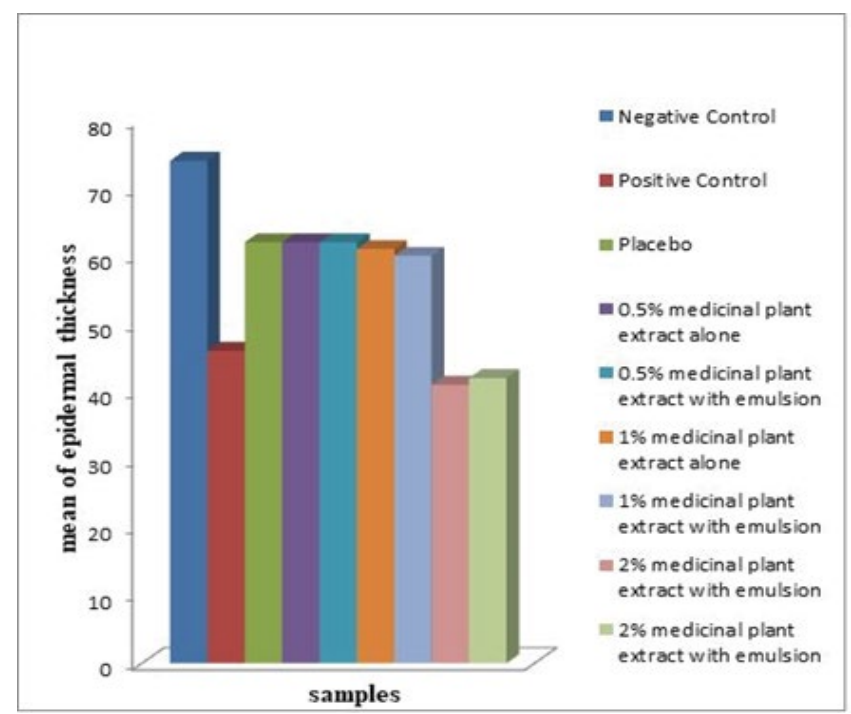

Figure 14: Effect of Kigelia africana extracts on epidermal thickness in Trichophyton mentagrophyte infected skin.

obtained for group $6 \mathrm{a}(41.33 \pm 0.69 \mu \mathrm{m})$ and group $6 \mathrm{~b}(41.72 \pm 0.76$ $\mu \mathrm{m})$ compared favorably with the value for the standard drug.

\section{Efficacy of Kigelia africana ethanol cream formulations against Malassezia furfur}

In the untreated group (group 1), moderate inflammation of the skin and foci of discontinuity of the epidermis were observed (Table 17). There was moderate presence of fungal hyphae which further indicated successful infection. Moderate tissue destruction was also observed in the group. There were few hair follicles enmeshed within the sparse connective tissue in the dermis which indicated that the dermatophyte is feeding on the follicles (Figure 15). Very few sebaceous glands were seen. No inflammation and tissue destruction was observed in the group treated with $1 \%$ clotrimazole (group 2) this is an indication that the drug was able to prevent the growth of the

\begin{tabular}{|c|c|c|c|c|c|}
\hline Group & $\begin{array}{c}\text { Fungal } \\
\text { hyphae }\end{array}$ & $\begin{array}{c}\text { Hair } \\
\text { follicles }\end{array}$ & $\begin{array}{c}\text { Sebaceous } \\
\text { gland }\end{array}$ & Inflammation & $\begin{array}{c}\text { Continuity/Tissue } \\
\text { destruction }\end{array}$ \\
\hline 1 & ++ & + & + & ++ & ++ \\
\hline 2 & - & +++ & ++ & - & - \\
\hline 3 & ++ & + & + & ++ & ++ \\
\hline $4 a$ & + & + & + & ++ & ++ \\
\hline $4 \mathrm{~b}$ & + & + & + & ++ & ++ \\
\hline $5 \mathrm{a}$ & + & + & ++ & ++ & ++ \\
\hline $5 \mathrm{~b}$ & + & + & ++ & ++ & ++ \\
\hline $6 \mathrm{a}$ & + & + & ++ & ++ & ++ \\
\hline $6 \mathrm{~b}$ & + & + & ++ & ++ & ++ \\
\hline \multicolumn{7}{|c|}{ Absent =-, Mild=+, Moderate=++, Marked=+++ } \\
\hline
\end{tabular}

Table 17: Mycological efficacy of Kigelia africana ethanol formulations against Malassezia furfur.

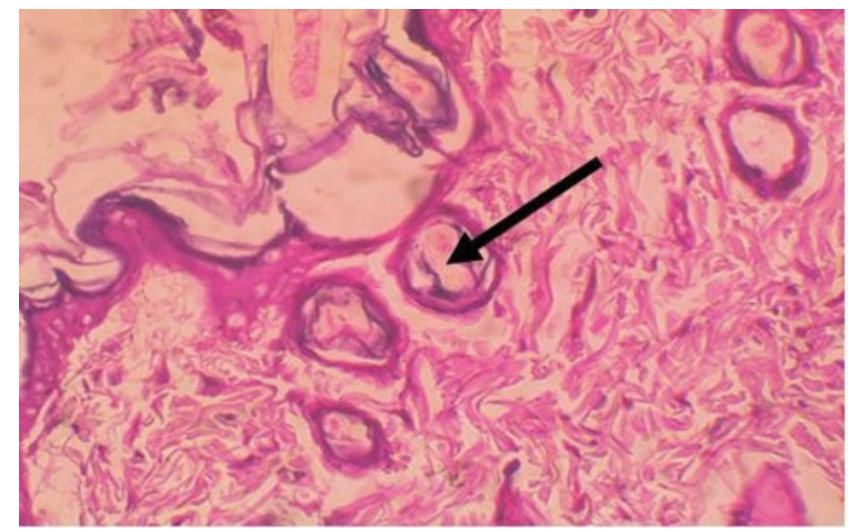

Figure 15: Isthmus lymphocytic mural folliculitis, H\&E stain, 100X.

hyphae by the dermatophyte. There were numerous hair follicles in the dermis and also moderate amount sebaceous glands. Inflammation and tissue destruction of the skin were moderate in the group treated with emulsion alone (group 3). There was moderate presence of fungal hyphae. There were few numbers of hair follicles and sebaceous glands in the dermis (Figure 16). In group $4 \mathrm{a}(0.5 \%$ plant extract alone) and group $4 \mathrm{~b}(0.5 \%$ plant extract in emulsion), inflammation and tissue destruction of the skin were moderate in the group (Table 17). There were few presences of fungal hyphae, hair follicles and sebaceous glands in the dermis. However, in groups $5 \mathrm{a}$ ( $1 \%$ plant extract alone) and $5 \mathrm{~b}$ ( $1 \%$ plant extract in emulsion), few amount of fungal hyphae and hair follicle were seen with moderate amount of sebaceous gland. The inflammation and tissue destruction of the skin were also moderate (Table 17). Same observation were recorded for groups $6 \mathrm{a}$ ( $2 \%$ plant extract alone) and $6 \mathrm{~b}$ ( $2 \%$ plant extract in emulsion).

The efficacy of the formulations on the keratin layer of the hair compared with the infected untreated control is shown in Figure 17. The value obtained $(26.03 \pm 0.30 \mu \mathrm{m})$ for the untreated control group 1 indicated that there was moderate infection of the hairs by the dermatophyte. The value obtained for the standard drug, $1 \%$ clotrimazole cream $(48.18 \pm 0.50 \mu \mathrm{m})$ indicated that there is significant prevention of attack by the dermatophyte on the keratin layer of the hair. The observation made for the group treated with the emulsion alone $(28.73 \pm 0.36 \mu \mathrm{m})$ indicated that the infection is gradually moving from moderate to mild. The results obtained for the other groups indicated that the moderate infection has been reduced to mild infection as can be seen in the groups treated with $0.5 \%$ Kigelia africana extract alone $(30.17 \pm 0.24 \mu \mathrm{m})$, the group treated with $0.5 \%$ Kigelia africana extract 


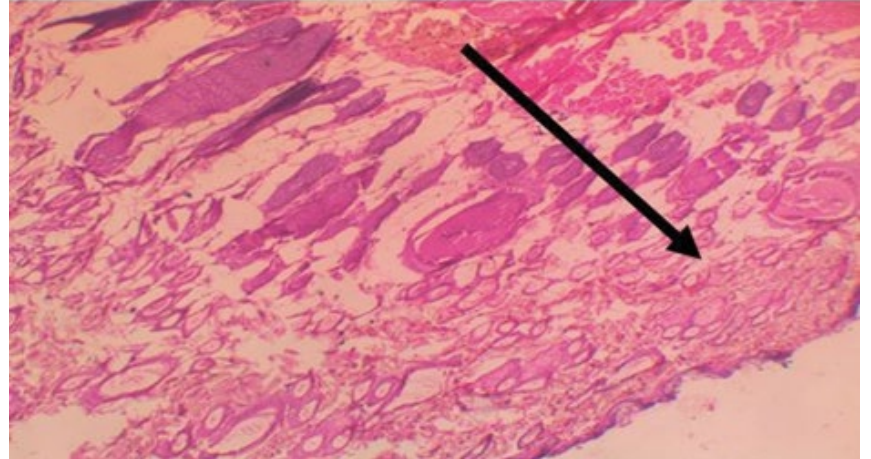

Figure 16: Infiltration of lymphosites, H\&E stain, 100X.

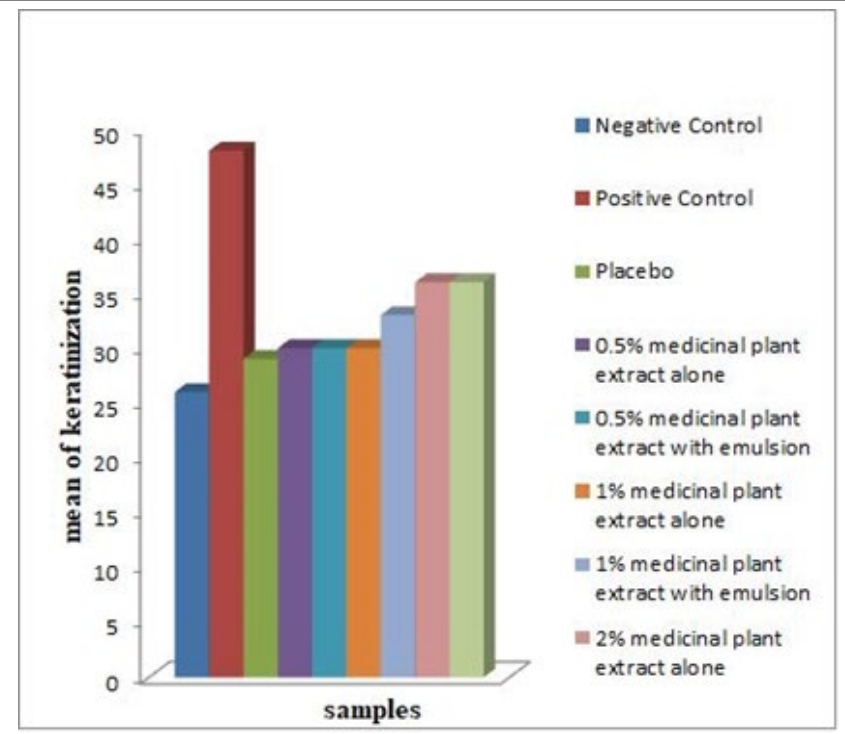

Figure 17: Effect of Kigelia africana extracts on keratinisation in Malassezia furfur infected skin.

emulsion $(30.14 \pm 0.14 \mu \mathrm{m}), 1 \%$ Kigelia africana extract alone (31.22 $\pm 0.79 \mu \mathrm{m})$ and $1 \%$ Kigelia africana emulsion $(31.66 \pm 0.65 \mu \mathrm{m})$ which were not different from one another. This implies that there is slight efficacy by the formulations. However, $2 \%$ Kigelia africana extract alone $(36.14 \pm 0.45 \mu \mathrm{m})$ and $2 \%$ Kigelia africana extract emulsion $(36.22 \pm$ $0.36 \mu \mathrm{m})$ showed higher mycological efficacy compared to the other formulations.

The result obtained for the epidermal thickness of the untreated group indicated that there was significant infection $(62.21 \pm 0.97 \mu \mathrm{m})$. However, the values obtained for the standard drug (43.71 \pm 0.53 $\mu \mathrm{m})$ can be said to effectively reduce the epidermal thickness thereby indicating high efficacy against the dermatophyte (Figure 18). The values obtained for emulsion alone $(62.14 \pm 0.76 \mu \mathrm{m}), 0.5 \%$ Kigelia africana extract $(60.75 \pm 0.93 \mu \mathrm{m}), 0.5 \%$ Kigelia africana extract emulsion $(60.37$ $\pm 0.63 \mu \mathrm{m}), 1 \%$ Kigelia africana extract $(59.92 \pm 0.34 \mu \mathrm{m}), 1 \%$ Kigelia africana emulsion $(58.00 \pm 0.82 \mu \mathrm{m}), 2 \%$ Kigelia africana extract alone $(57.89 \pm 0.76 \mu \mathrm{m})$ and $2 \%$ Kigelia africana emulsion with extract (56.91 $\pm 0.85 \mu \mathrm{m})$ in reducing the epidermal thickness cannot be said to be significant compared with the untreated control.

\section{Comparative efficacy of the formulations against the dermatophytes}

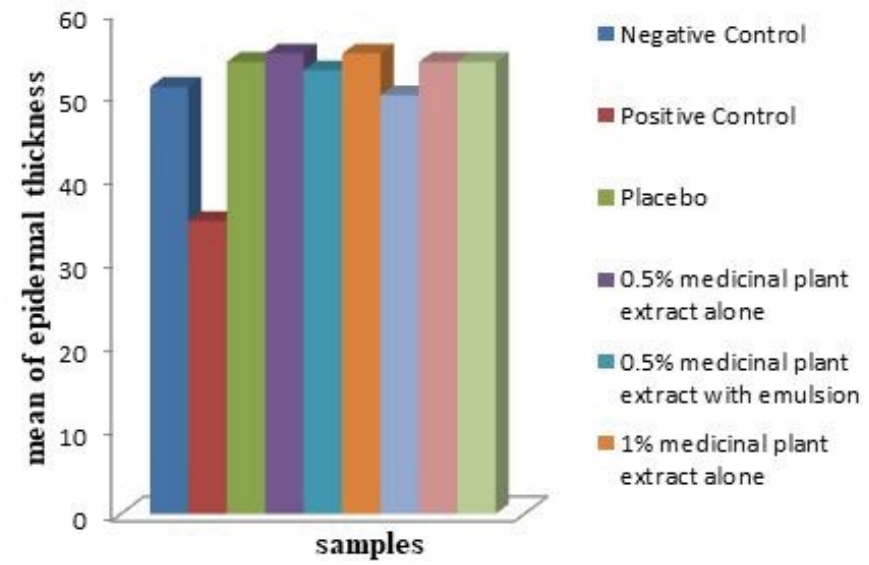

Figure 18: Effect of Kigelia africana extracts on epidermal thickness in Malassezia furfur infected skin.

\begin{tabular}{|c|c|c|}
\hline Dermatophyte & Keratin layer $(\boldsymbol{\mu m})$ & $\begin{array}{c}\text { Epidermal thickness } \\
(\boldsymbol{\mu m})\end{array}$ \\
\hline Control (Uninfected rat) & $55.46 \pm 0.5$ & $31.24 \pm 0.21$ \\
\hline M. audouinii & $31.37 \pm 0.53$ & $44.11 \pm 0.03$ \\
\hline T. mentagrophyte & $37.01 \pm 0.39$ & $41.72 \pm 0.76$ \\
\hline E. floccosum & $30.53 \pm 0.25$ & $52.41 \pm 0.12$ \\
\hline M. furfur & $36.22 \pm 0.36$ & $56.91 \pm 0.85$ \\
\hline
\end{tabular}

Table 18: Comparative efficacy of the formulations against the dermatophytes.

Evaluation of the formulations tested indicated that their efficacy against the dermatophytes is concentration dependent (Table 18). Emulsion containing $2 \%$ of extracts possess significant mycological efficacy against dermatophytic infection caused by all the dermatophytes. The high efficacy could be explained on the basis of pharmacokinetics of the extracts on the skin. Data obtained for keratinization indicated that the cream was most statistically significant $(\mathrm{P}<0.05)$ with $37.01 \pm 0.39 \mu \mathrm{m}$ against Trychophyton mentagrophyte $>$ Malassezia furfur $(36.22 \pm 0.36 \mu \mathrm{m})>$ Microsporum audouinii $(31.37 \pm$ $0.53 \mu \mathrm{m})>$ Epidermophyton floccosum $(30.53 \pm 0.25 \mu \mathrm{m})$. Also the cream was able to reduce epithermal thickness with the value $(41.72 \pm 0.76$ $\mu \mathrm{m})$ which is significant $(\mathrm{P}<0.05)$ against Trychophyton mentagrophyte $>$ Microsporum audouinii $(44.11 \pm 0.03 \mu \mathrm{m})>$ Epidermophyton floccosum $(52.41 \pm 0.12 \mu \mathrm{m})>$ Malassezia furfur $(56.91 \pm 0.85 \mu \mathrm{m})$. The result obtained agrees with the works carried out on Kigelia africana by Jeyachandran and Mahesh [11-16] who in their study showed that the medicinal plant is medicinal for a managing a number of diseases. Similarly, previous data obtained during the in vitro antifungal tests we carried out on Kigelia africana further support the efficacy of the formulations. Various scientific studies indicated the usefulness of developing drugs from plants extract for treating skin ailments and it has been previously by Oyedeji and Bankole $[9,17-20]$ that formulation of Kigelia africana extract as topical cream may lead to enhancement of stability and acceptability of the active ingredient. We can therefore conclude that the topical preparation is highly effective against skin damage caused by various dermatophytes [21-24].

\section{Acknowledgement}

We sincerely acknowledge the support of Dr. A Raheem of Spectralab Medical and Diagnostic Services, Sagamu, Ogun State. 
Citation: Fawehinmi AB, Oyedeji FO (2018) Stability and Efficacy of Anti-dermatophyte Creams From Extract of Kigelia africana Leaves. Altern Integ Med 7: 274. doi: 10.4172/2327-5162.1000274

\section{References}

1. Phillips RM, Rosen T (2013) Topical antifungal agents. In Wolverton SE. Comprehens Dermatol Ther 3: 460-472.

2. Moghimipour E, Ameri A, Saudatzadeh A, Salimi A, Siahpoosh A (2009) Formulation of an anti-dermatophyte cream from hydro-alcoholic extract of eucalyptus camaldulensis leaves. Jundishapur J Natur Pharma Prod 4: 32-40.

3. Babayi H, Kolo I, Okogun JI, ljah UJ (2004) The antimicrobial activities of methanolic extracts of Eucalyptus camaldulensis and Terminalia catappa against some pathogenic microorganisms. Biokemistri; 16: 106-111.

4. Scherrer AM, Motti R, Weckerle CS (2005) Traditional plant use in the areas of Monte Vesole and Ascea, Cilento National park. J Ethnopharmacol 97: 129143.

5. Kyle AA, Dahl MV (2004) Topical therapy for fungal infections. Am J Clin Dermatol 5: 443-451.

6. Havlickova B, Czaika VA, Friedrich M (2008) Epidemiological trends in skin mycoses worldwide. Mycoses 51: 2-15.

7. Aiyelola AA, Bello OA (2006) Ethnobotanical potentials of common herbs in Nigeria: A case study of Enugu state. Edu Res Rep 1: 16-22.

8. Olatunji AG, Atolani O (2009) Comprehensive scientific demystification of Kigelia africana: A review. African J Pure Appl Chem 3: 158-164.

9. Oyedeji OF, Bankole-Ojo OS (2012) Quantitative evaluation of the antipsoriatic activity of sausage tree (Kigelia africana). African J Pure Appl Chem 6: 214-218.

10. Owolabi OJ, Omogbai EKI, Obasuyi O (2007) Antifungal and antibacterial activities of the ethanolic and aqueous extract of Kigelia africana (Bignoniaceae) stem bark. African J Biotechnol 6:14.

11. Jeyachandran R, Mahesh A (2007) Antimicrobial evaluation of Kigelia africana (Lam). Res J Microbiol 2: 645-649.

12. Abubacker MN, Ramanathan R, Kumar ST (2008) Natural product radiance 7: 6-9.

13. Acharya D, Shrivastava A (2008) Indigenous herbal medicines: Tribal formulations and traditional herbal practices, Aavishkar Publishers, India, 1-44.
14. Akinyemi KO, Olukayode O, Okwara EC, Ibe CC, Fasuro KA (2005) Screening of crude extracts of six medicinal plants used in south-west Nigerian unorthodox medicine for anti-methicillin resistant Staphylococcus aureus activity. BMC Complement Altern Med 5: 6.

15. De-Benedetto A (2009) Atopic dermatitis: A disease caused by innate immune defects? J Invest Dermatol 129: 14-30.

16. Eleazu CO, Eleazu KC, Awa E, Chukwuma SC (2012) Comparative study of the phytochemical composition of the leaves of five Nigerian medicinal plants. J Biotechnol Pharma Res 3: 42-46.

17. Ghannoum M, Isham N, Verma A, Plaum S, Fleischer A, et al. (2013) In vitro antifungal activity of naftifine hydrochloride against dermatophytes. Antimicro Agents Chemother 57: 4369-4372.

18. Grace OM, Light ME, Lindsey KL, Mulholland DA, Van Staden J, et al. (2002) Antibacterial activity and isolation of active compounds from fruit of the traditional African medicinal tree Kigelia africana. South African J Botany 68: 220-222.

19. Hosseininejad M, Ebrahimi A, Hosseini $F$ (2009) Isolation of Epidermophyton floccosum from a persian squirrel (Sciurusanomalus). Compar Clinic Pathol 19: 215-216.

20. Kumar R, Kumar T, Kamboj V, Chander H (2012) Pharmacological evaluation of ethanolic extract of Kigelia pinnata fruit against ethylene glycol induced urolithiasis in rats. Asian J Plant Sci Res 2: 63-72.

21. Lawal HO, Etatuvie SO, Fawehinmi AB (2012) Ethnomedicinal and pharmacological properties of Morinda lucida. J Natur Prod 5: 93-99.

22. Marks JG, Miller J (2006) Lookingbill and marks' principles of dermatology, $4^{\text {th }}$ edtn, Elsevier, USA.

23. Meduri NB, Travis V, Heather R, Heidi J (2007) Phototherapy in the management of atopic dermatitis: A systematic review. Photodermatol Photoimmunol Photomed 23: 106-112.

24. Tadros T (2004) Application of rheology for assessment and prediction of the long-term physical stability of emulsions. Adv Colloid Interface Sci 108-109: 227-258. 